\title{
THE USE OF SELF-EXCITED VIBRATIONS FOR DYNAMIC STRAIN MEASUREMENTS CARRIED OUT BY VIBRATING WIRE TENSOMETERS
}

\begin{abstract}
This study examines a set of vibrating wire extensometers in which a van der Pol generator has been used to maintain the natural vibrations of the wire. Excited in this way, self-exited vibrations allow for uninterrupted strain measurements over time, including fast-changing strains as well as chaotic nature strains. For the two typical vibrating wire gauges used in the industry, the impact of the wire extension speed on its metrological characteristics and applicability has been analyzed.
\end{abstract}

Keywords: vibrating wire transducers, self-excited vibrations, tensometers

\section{WYKORZYSTANIE DRGAŃ SAMOWZBUDNYCH DO DYNAMICZNYCH POMIARÓW ODKSZTAECEŃ REALIZOWANYCH ZA POMOCA TENSOMETRÓW Z DRGAJACA STRUNA}

$W$ pracy poddano analizie układ ekstensometru strunowego, $w$ którym $w$ celu utrzymania niegasnacych drgań własnych struny zastosowano generator van der Pola. Wzbudzone $w$ ten sposób drgania samowzbudne pozwalaja na nieprzerwany $w$ czasie pomiar odksztatcen, $w$ tym również odkształceń szybkozmiennych $i$ o charakterze chaotycznym. Dla dwóch typowych czujników strunowych stosowanych w przemyśle przeanalizowano wptyw szybkości rozciagania struny na jej właściwości metrologiczne i możliwości zastosowania.

Stowa kluczowe: czujniki strunowe, drgania samowzbudne, tensometry

\section{INTRODUCTION}

The vibrating wire (VW) measuring technique was created in the 1930s. The first vibrating wire transducer, called an acoustic transducer, was patented in August 16, 1931 by Frenchman Andre Coyne. Due to its properties, the vibrating wire sensors are used wherever the high resistance of measuring devices to the environmental conditions (McRae, Simmonds 1991), long-term stability of the measurements over time (Simmonds 2013), and great distance between the sensors and measuring apparatus (up to $16 \mathrm{~km}$ ) are required. These transducers have found their main application in geotechnics and hydraulic engineering to measure slowly-changing quantities. Sensors containing vibrating wire are used to build a long-term structural health monitoring system for structures such as bridges, stadiums, arenas, and large-area objects (Bednarski, Sieńko 2013). More and more, attempts are being made to use these gauges to examine dynamic processes.

Since the beginning of the existence of VW gauges, there have been ongoing attempts to build electronic systems operating in dynamic mode. The difficulty is to build a measuring apparatus that will keep the sensor in steady-state vibrations and, at the same time, collect measurement data. There were different solutions for this problem. From systems performing sensor excitation at a given period of time (Kanciruk 2004 Feldman et al. 2006) through sensors requiring the use of two coils, where one coil was a measuring coil and the second an excitation coil. Continuous research and the development of electronic systems lead to the appearance of multi-channel devices on the market implementing dynamic measurements with standard VW transducers (Cornelsen, Jacobsen 2012). In recent years, a new method for dynamic measurements using self-excited wire vibrations has been developed in Poland (Cieplok, Kopij 2013). This method enables a new application of the vibrating wire sensors; e.g., for the design of monitoring systems for structures, or the construction of measurement systems to observe dynamic processes over long periods of time. However, due to their design, such solutions raise questions about the limitations of VW sensor applications for measuring rapid changes in distance. This article will examine the behaviour of vibrating wire extensometers undergoing dynamic influences, while the wire will perform self-excited oscillations (Cieplok, Kopij 2013).

\section{DESIGN AND BRIEF OF VIBRATING WIRE STRAIN SENSORS}

Vibrating wire extensometers, also called vibrating wire strain gauges, have the simplest design. Inside the housing, the vibrating wire is stretched between two mounting blocks (Fig. 1).

\footnotetext{
* AGH University of Science and Technology, Faculty of Mechanical Engineering and Robotics, Krakow, Poland; e-mail: cieplok@agh.edu.pl

** Krakow University of Technology, Institute of Building Materials and Structures, Faculty of Civil Engineering, Krakow, Poland
} 


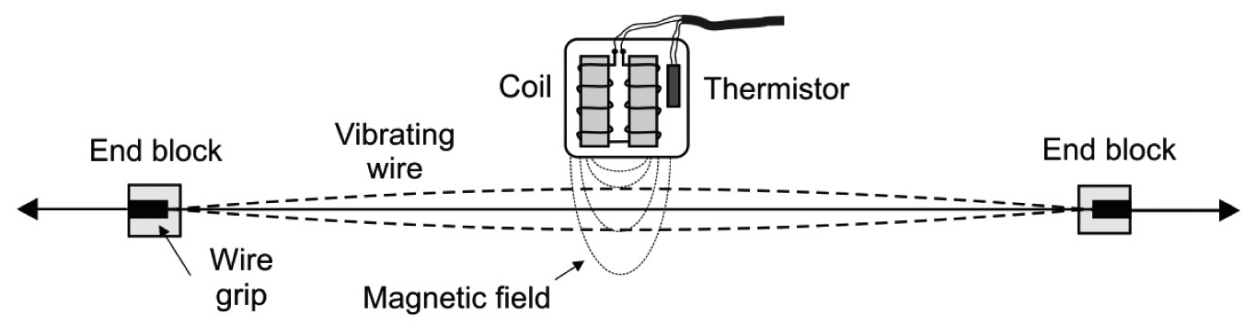

Fig. 1. Vibrating wire strain gauge design (without protective tube)

A change of distance between the blocks causes a change in the tensile stress of the wire as well as its length; and thus, the change of its natural frequency. By using the same electromagnetic coil, the excitation of the wire is carried out, and the measurement signal as an alternating voltage induced in the coil by the wire vibration within the magnetic field is read.

Depending on the length of the sensor-measuring base, the vibrating wire has a different length. For the examined sensors, the length of wires is equal to 50.80 and $158.76 \mathrm{~mm}$ (Fig. 2), respectively. With a change in wire length, the frequency range of its transverse vibrations changes as well. This range is $1400-3500 \mathrm{~Hz}$ for a wire of $50.80 \mathrm{~mm}$ and 450 to $1250 \mathrm{~Hz}$ for a wire of $158.76 \mathrm{~mm}$.

The name of vibrating wire strain gauges comes from the widely-accepted method of converting measurement data in which the results are presented in dimensionless units according to equation (1). Quantity $\varepsilon$ obtained in this way is the strain that (due to the multiplier of $10^{6}$ ) is called microstrain $[\mu \varepsilon]$ :

$$
\varepsilon=\frac{\Delta L}{L} \cdot 10^{6}[\mu \varepsilon]
$$

where $\Delta L$ is the change of the wire length related to the change of the measured quantity and $L$ is the initial length of wire.

a)

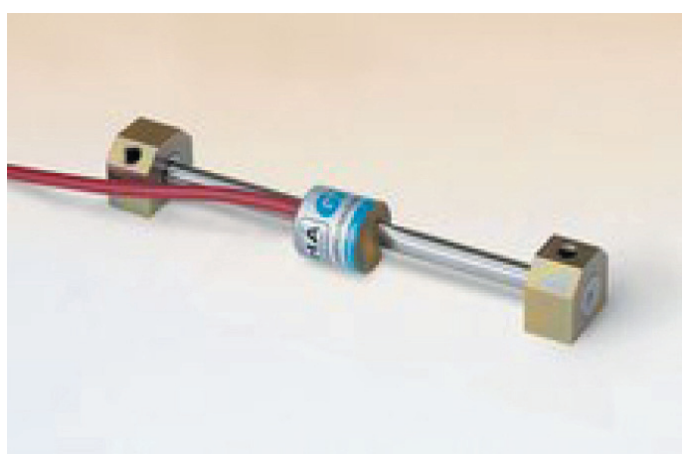

Within the article, a transducer model will be presented in which force (change of the measured value) is achieved by changing the position of the wire's free end by the value of $\Delta L$. It is for this reason that the authors will use the term "displacement" to define the change of the wire end position in relation to the strain sensors by the value of $\Delta L$ in the following parts of the article.

\section{MATHEMATICAL MODEL}

The model of a VW sensor in which the wire is extended longitudinally and executes transverse vibrations has been studied. The sensor model was built based on the description of a wire extended by longitudinal force presented by G. Cieplok and L. Kopij (2013). The analyzed model of the strain sensor is shown in Figure 3. Due to the kinematic displacements of the wire end, the rubber seal elements inside the sensor body and the spring for initial tension of the wire have been omitted.

In the succeeding description, the notation was assumed as follows: $A\left[\mathrm{~m}^{2}\right]$ - cross-sectional area of the wire; $\rho\left[\mathrm{kg} / \mathrm{m}^{3}\right]$ - material density; $\beta_{x}, \beta_{y}\left[\mathrm{Ns} / \mathrm{m}^{2}\right]$ - damping coefficients at longitudinal and transverse directions related to the length unit, respectively; $d x[\mathrm{~m}]$ - elementary section of the wire; $y[\mathrm{~m}]$ - vertical displacement; $u[\mathrm{~m}]$ - displacement along the wire; $T[\mathrm{~N}]$ - force of wire tension; $U(t)$ - displacement of movable end of the wire.

b)

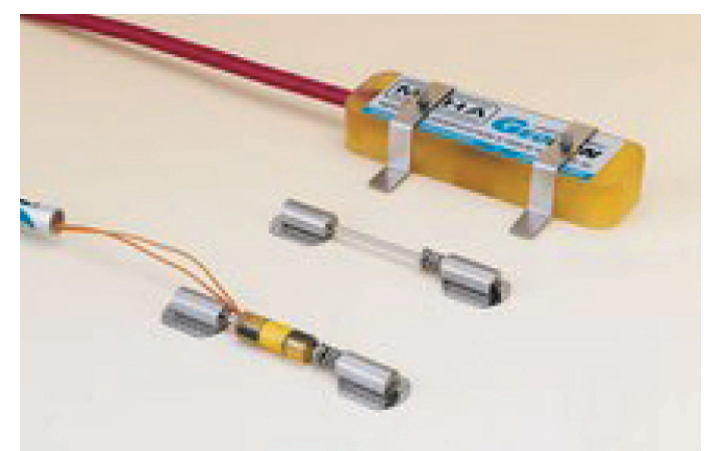

Fig. 2. View of vibrating wire sensors:

a) measuring base of $150 \mathrm{~mm}$; b) measuring base of $50 \mathrm{~mm}$

[Courtesy of Geokon Inc.] 


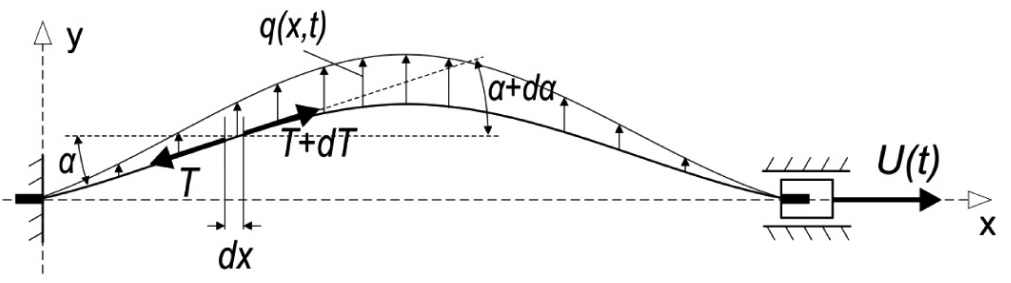

Fig. 3. Vibrating wire strain sensor model

Assuming the small values of the angles, the variable value of tensile force along the wire and the uniformity of the wire material, the sensor model is described by two equations (2):

$$
\begin{gathered}
\frac{\partial^{2} u(x, t)}{\partial t^{2}}-\frac{E}{\rho} \frac{\partial^{2} u(x, t)}{\partial x^{2}}+\frac{\beta_{x}}{A \rho} \frac{\partial u(x, t)}{\partial t}=0 \\
\rho A \frac{\partial^{2} y(x, t)}{\partial t^{2}}+\beta_{y} \frac{\partial y(x, t)}{\partial t}-T(x, t) \frac{\partial^{2} y(x, t)}{\partial x^{2}}= \\
=E A \frac{\partial y(x, t)}{\partial x} \cdot \frac{\partial^{2} u(x, t)}{\partial x^{2}}+q(x, t)
\end{gathered}
$$

The way of attaching the wire in the sensor imposes boundary conditions. In the analyzed case, the wire is fixed at one side. The other end is guided in a straight line and is subjected to kinematic excitation (which represents the strain that is measured by the sensor). For these assumptions, boundary conditions (3) and (4) have been stated wherein $U(t)$ is the displacement of the movable wire end at the $x$ direction.

$$
\begin{aligned}
& y(0, t)=0 \\
& y(l, t)=0 \\
& u(0, t)=0 \\
& u(l, t)=U(t)
\end{aligned}
$$

It is necessary to maintain the wire in a steady state of vibrations to perform the dynamic measurements. This mode of operation was achieved by conducting the wire to the self-excited vibrations according to the idea presented in Figure 4 (Cieplok, Kopij 2013).

Self-excited vibrations occur in non-conservative systems and have a feature that makes them capable of self-replenishing lost energy, and their amplitude and frequency are determined only by the physical parameters of the system.

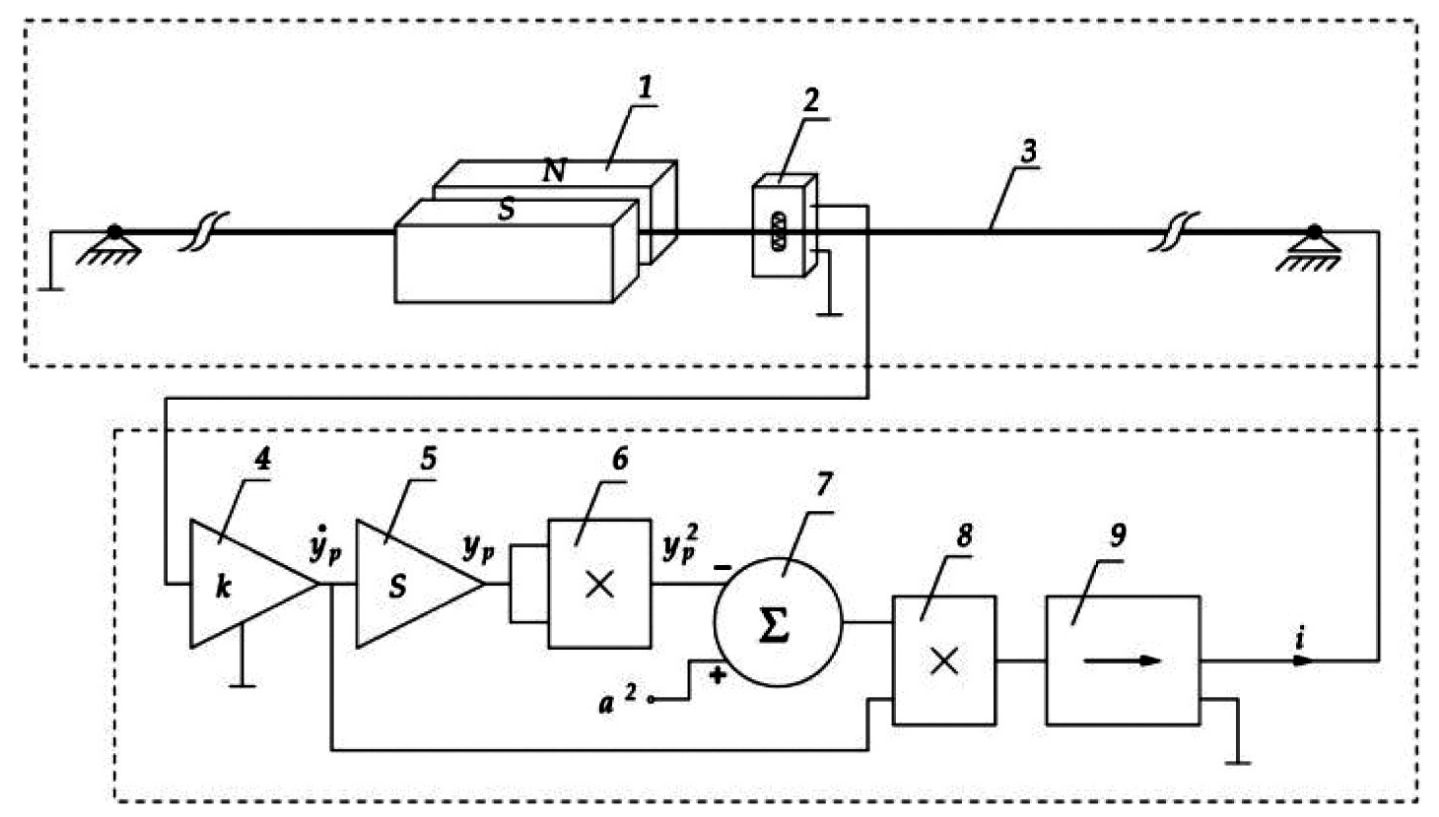

Fig. 4. Sketch of motion control system of wire gauge based on van der Pol equation: 1 - permanent magnet; 2 - magneto-electric transducer; 3 - wire; 4 - voltage amplifier; 5 - integrating block; 6 \& 8 - multiplying blocks; 7 - adding block; 9 - current amplifier; $y_{p}$ - displacement of the wire in position of the magnetoelectric sensor 
A characteristic feature of this kind of excitation is that the steady-state frequency is not dependent on the frequency of the excitation force. This approach allows us to analyze the properties of a mechanical system without the restrictions caused by commercially-available electronic systems, such as the loss of resonance or maximum sampling frequency offered by electronic devices.

As a result of the introduction of the van der Pol oscillator, equation (2b) takes form (5):

$$
\begin{gathered}
\rho A \frac{\partial^{2} y(x, t)}{\partial t^{2}}+\beta_{y} \frac{\partial y(x, t)}{\partial t}-T(x, t) \frac{\partial^{2} y(x, t)}{\partial x^{2}}= \\
=E A \frac{\partial y(x, t)}{\partial x} \cdot \frac{\partial^{2} u(x, t)}{\partial x^{2}}+ \\
+\frac{\varepsilon_{f}}{\rho A}\left(a^{2}-y^{2}\left(\frac{l}{2}, t\right)\right) \cdot \dot{y}\left(\frac{l}{2}, t\right) \cdot q_{S F}\left(x-\frac{l}{2}\right)
\end{gathered}
$$

where term $\frac{\varepsilon_{f}}{\rho A}\left(a^{2}-y^{2}\left(\frac{l}{2}, t\right)\right) \cdot \dot{y}\left(\frac{l}{2}, t\right) \cdot q_{S F}\left(x-\frac{l}{2}\right)$ is responsible for the interaction of the wire with the magnetic field of the electromagnet coil that is coupled with the van der Pol oscillator: $q_{S F}\left(x-\frac{l}{2}\right)$ - dimensionless shape function; $\varepsilon_{f}\left[\mathrm{~kg}^{2} / \mathrm{sm}^{4}\right]$ - parameter; $a[\mathrm{~m}]$ - parameter.

\section{SIMULATION TESTS}

Based on the mathematical model, computer simulations of the movement of the wire subjected to variable extension

a)

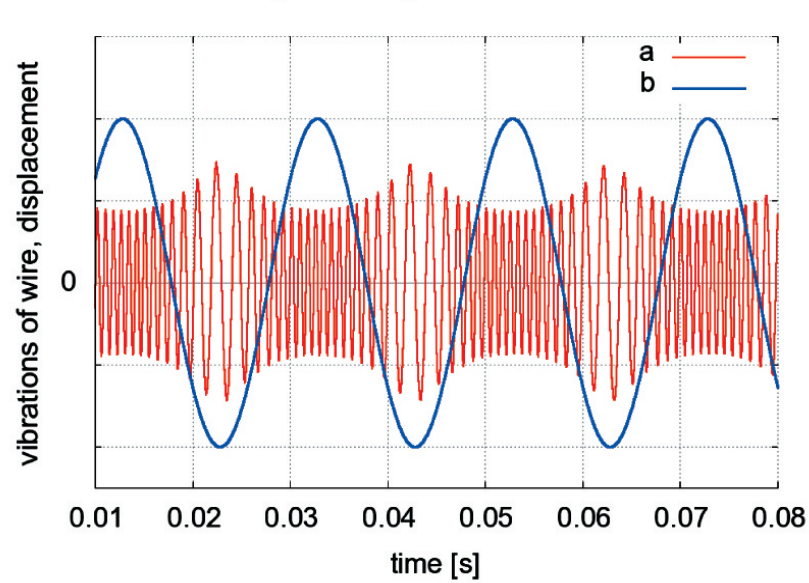

over time were carried out. During the experiment, the wire elongation was changed, and then the frequency of the transverse vibration was determined. Based on the results, the wire elongation was reconstructed by equation (6) in order to compare it with the course given.

A characteristic feature of VW sensors is that the change of a measured quantity (in this case, strain) causes a change in the transverse vibration frequency of the wire. This process is shown in Figure 5a. With an increase in a wire's strain, its frequency of transverse vibration is also increased, and vice versa. In the analyzed numerical experiment, the frequency of the transverse vibrations of the wire was determined by measuring half of the oscillation period. The consequence of this method is that, at higher frequencies of transverse vibration, we obtain more samples per unit of time (a shorter period of vibrations) than within lower frequencies (a longer period). This effect is shown in Figure 5b.

To recalculate the wire elongation that occurs on changes in frequency of the transverse vibration obtained from the model, the following function was used:

$$
\Delta L=G \cdot\left(f_{1}^{2}-f_{0}^{2}\right) \cdot 10^{-9} \cdot L
$$

where:

$\Delta L-$ is wire elongation [m],

$f_{1}$ - current frequency of wire transverse vibration,

$f_{0}$ - initial frequency of wire transverse vibration,

$G$ - calibration factor,

$L$ - wire length.

b)

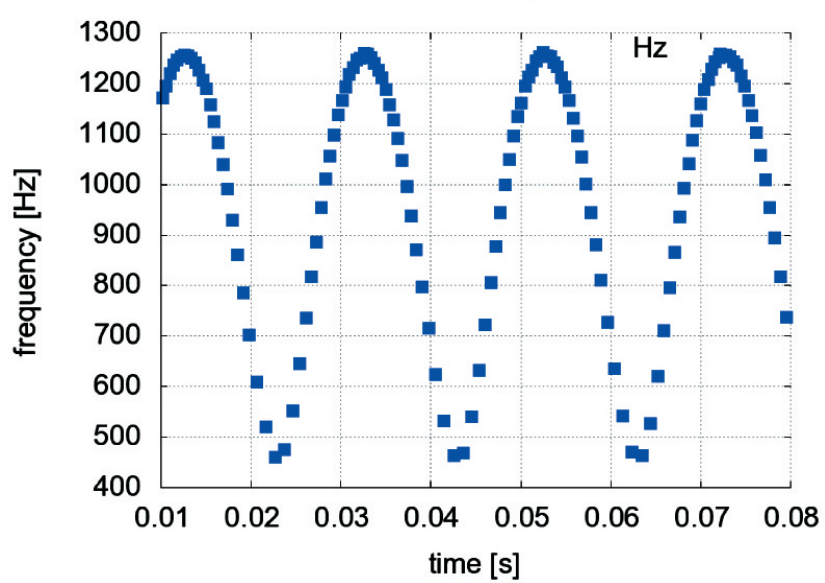

Fig. 5. Results of numerical simulations: a) change of wire frequency caused by change of wire strain, curve "a" represents vibrations of wire over time, and curve " $b$ " the change of the given displacement; $b$ ) changeable number of frequency samples determined by measuring half of oscillation period of wire for a constant frequency of strain changes that equal $50 \mathrm{~Hz}$ 
VW strain sensors with two lengths of measuring base equal to $50 \mathrm{~mm}$ and $150 \mathrm{~mm}$ were studied. The physical parameters of the model for these cases have the following values:

$\begin{array}{lcc} & \text { model 1 } & \text { model } 2 \\ \text { Operation frequency [Hz] } & 1400-3500 & 450-1250 \\ \text { Young's modulus E [GPa] } & 206.8 & 206.8 \\ \text { Active wire length 1 [m] } & 0.0508 & 0.15875 \\ \text { Diameter of wire D [m] } & 0.0002 & 0.0002 \\ \text { Density } \rho\left[\mathrm{kg} / \mathrm{m}^{3}\right] & 7833 & 7833 \\ \text { Calibration factor G } & 0.375 & 3.62\end{array}$

Below the simulation results for selected cases of force are presented.

a)

Frequency

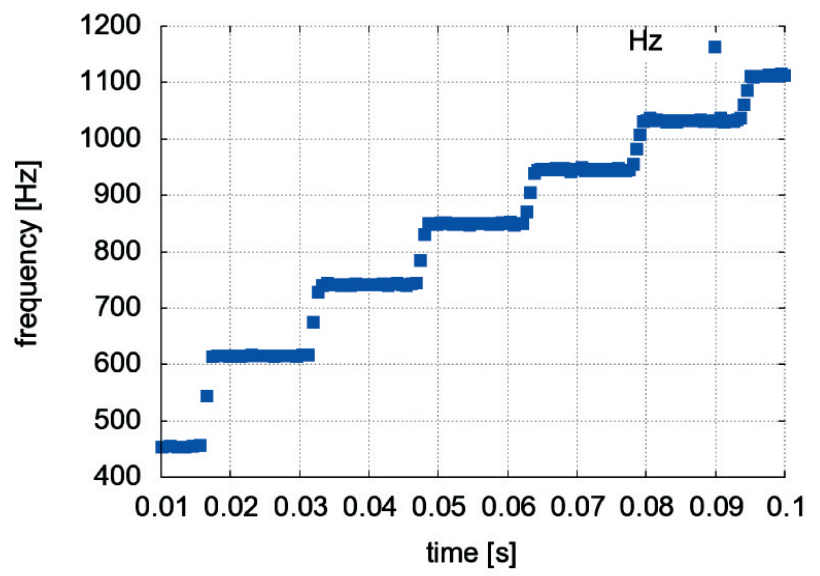

\subsection{The step change of the measured value}

The first stage of the research was to verify sensor resistance for the step change of the measured value. As a result of the simulation, it was found that the response of the vibrating wire to a step change in the displacement of $\Delta L$ of its free end was practically instantaneous. A new frequency is established at the time when a new value of $\Delta L$ is applied (Figs. 6a, b). The vibrating wire retains the first mode of natural vibrations until exceeding the maximum speed of force increase. The calculation results are shown in Figures $6 \mathrm{a}$ and $6 \mathrm{~b}$ for a wire length of $158.75 \mathrm{~mm}$ and Figures $7 \mathrm{a}$ and $7 \mathrm{~b}$ for a wire length of $50.80 \mathrm{~mm}$. In both cases, the calculated displacements coincide with the given ones.

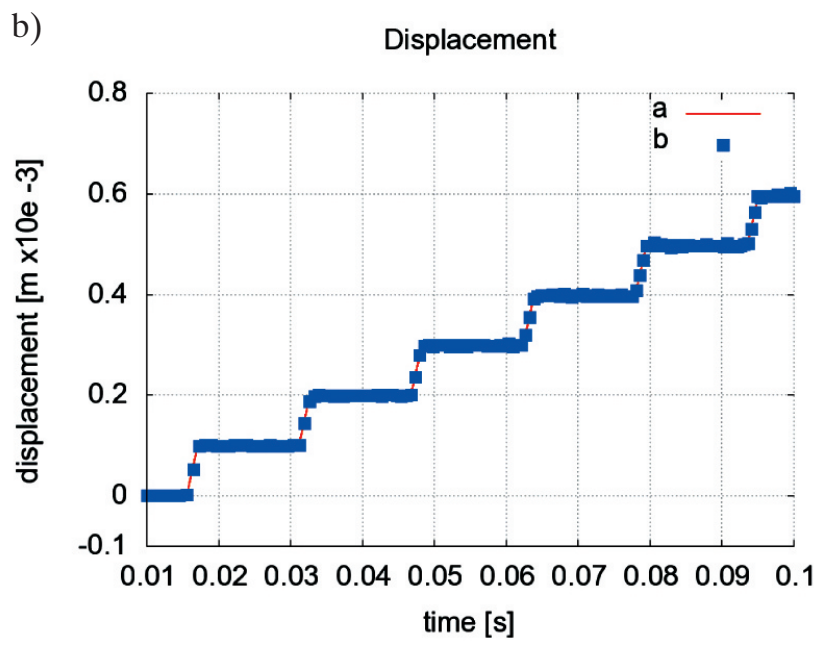

Fig. 6. Results of numerical simulations: a) course of changes in wire frequency during step change in displacement $\Delta L$, and b) comparison of displacement given (curve "a") and displacement that is calculated taking into account determined frequency of transverse wire vibration (curve "b"). Results for wire length equal to $0.15875 \mathrm{~m}$

a)

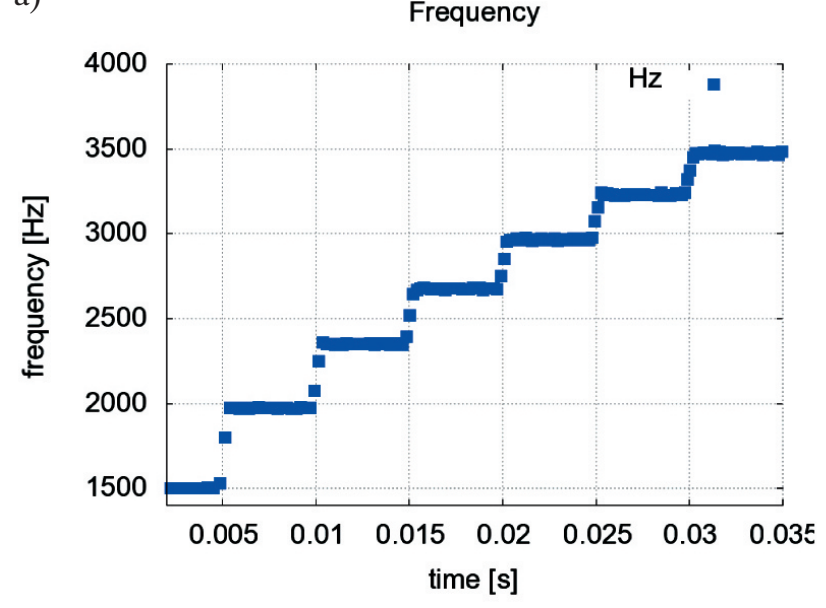

b)

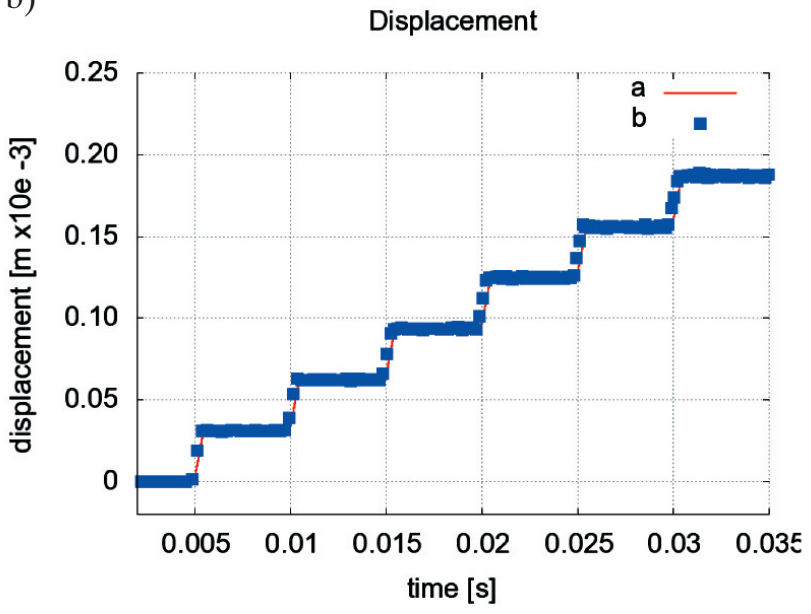

Fig. 7. Results of numerical simulations: a) course of changes in wire frequency during step change in displacement $\Delta L$, and b) comparison of displacement given (curve "a") and displacement that is calculated taking into account determined frequency of transverse wire vibration (curve "b"). Results for wire length equal to $0.0508 \mathrm{~m}$ 
The maximum speed of the wire elongation increase was specified, for which the wire retains the first vibration mode. For a wire length of $158.75 \mathrm{~mm}$, this speed is equal to $0.641 \mathrm{~m} / \mathrm{s}$. For a wire length of $50.80 \mathrm{~mm}$, this velocity is equal to $0.020 \mathrm{~m} / \mathrm{s}$. Exceeding the designated speeds of the wire elongation increase causes an excitation of higher vibration modes (which ended the possibility of further measurements). The reason for this limitation may result from features of the model used that do not take into account the transverse bending stiffness of the wire.

\subsection{Harmonic change of the measured value}

The next part of the study was to determine sensor usefulness in measuring quantities changing in a harmonic way. The aim was to specify the maximum frequency of the change that still allows us to measure the analyzed value. As the starting point, half of the sensor measuring range was taken. The range of the strain change covers the whole range of the sensor, which is $+/-$ half of the measuring

a)

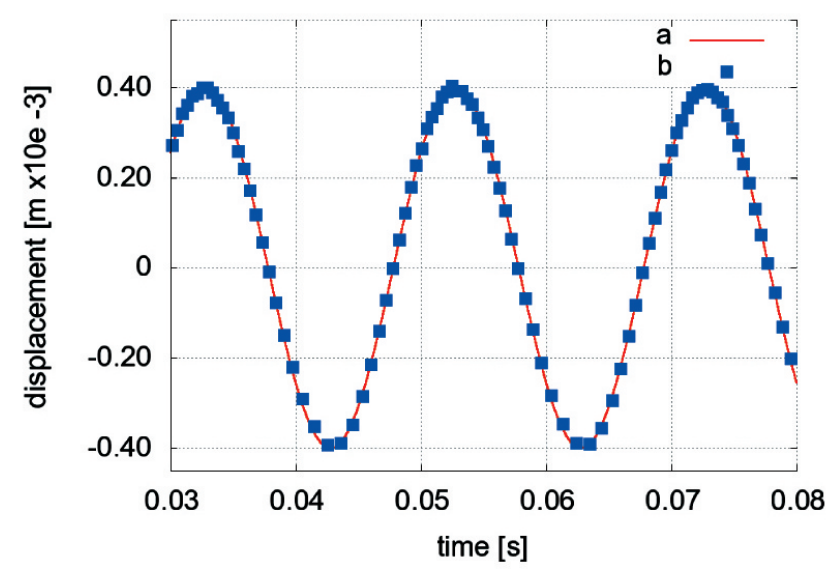

c)

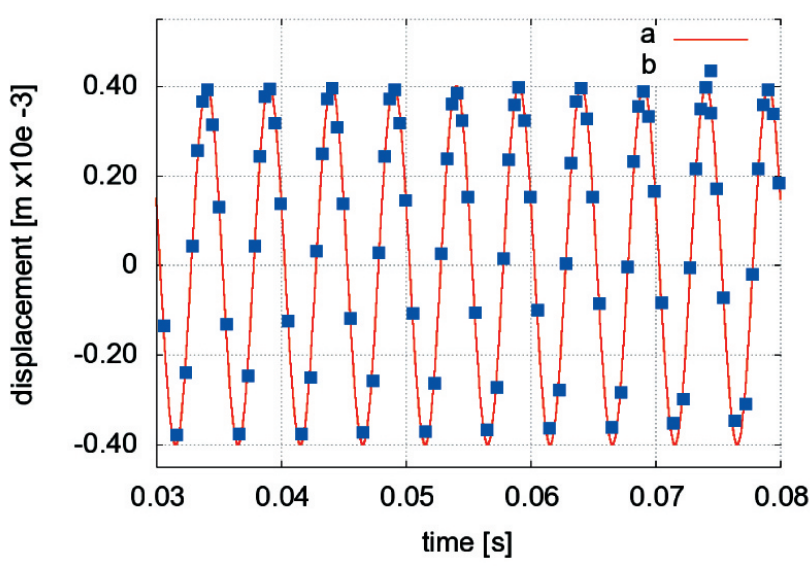

range. Tests were carried out for harmonic excitations with frequencies from 0 to $450 \mathrm{~Hz}$ for a wire length of $0.15875 \mathrm{~m}$ (Fig. 8) and from 0 to $1500 \mathrm{~Hz}$ for a wire length of $0.05080 \mathrm{~m}$ (Fig. 9), respectively, with a step of $10 \mathrm{~Hz}$. As a result of the simulations, it was found that the harmonic changes in wire elongations cause changes in the harmonic frequency of the wire vibration while maintaining the first vibration mode in the whole range of frequencies considered. Below, the results of the calculations for selected frequencies of forces are presented.

While determining the frequency of wire transverse vibrations for each half cycle of oscillation, the maximum frequency of forcing signal (which is possible to measure with the VW gauge) is equal to the lower natural frequency of operating wire vibrations in the transverse direction. While determining wire frequency every half-period, we obtain four samples of the signal at one period of forcing vibration, which allows for their reconstruction according to the sampling theorem. For a wire length of $0.15875 \mathrm{~m}$, this is $450 \mathrm{~Hz}$; for $0.05080 \mathrm{~m}-1500 \mathrm{~Hz}$.

b)

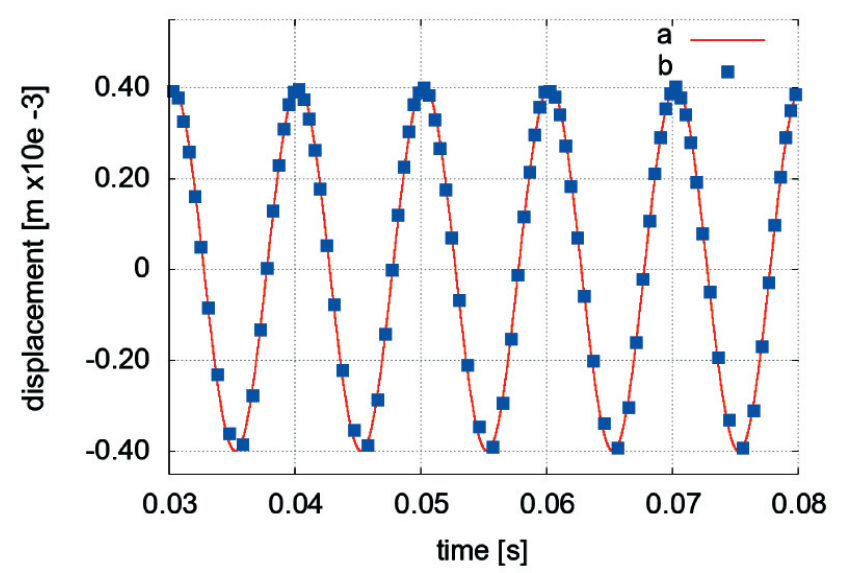

d)

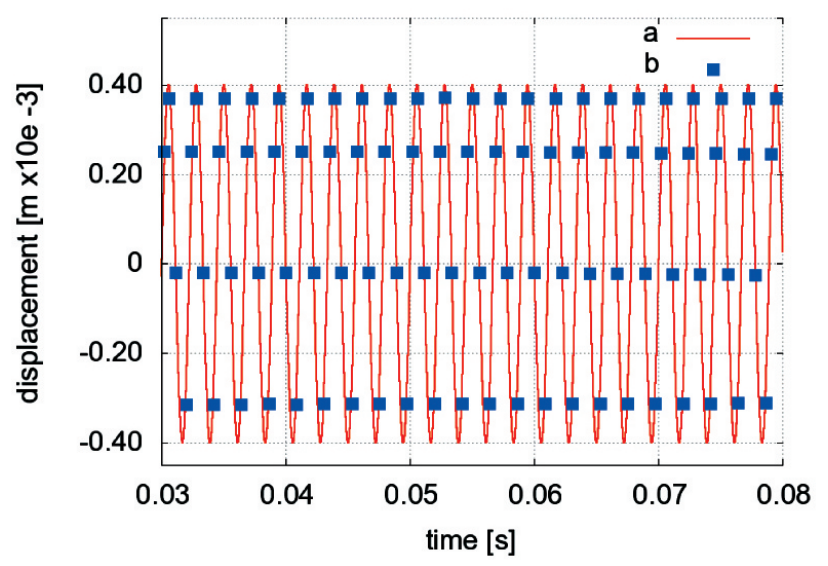

Fig. 8. Displacements given (curve "a") and calculated (curve "b") based on wire frequencies determined from model for force frequencies of: a) $50 \mathrm{~Hz}$; b) $100 \mathrm{~Hz}$; c) $200 \mathrm{~Hz}$; d) $450 \mathrm{~Hz}$. Wire length - $0.15875 \mathrm{~m}$ 
a)

Displacement

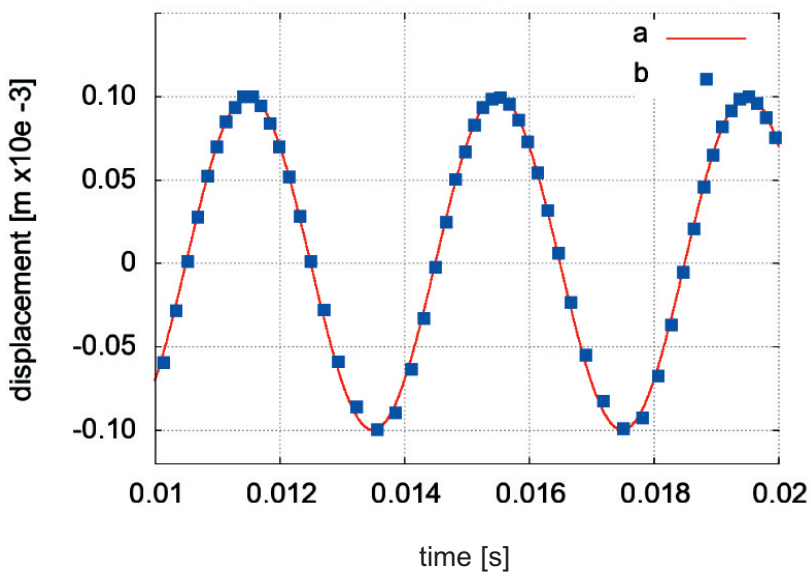

c)

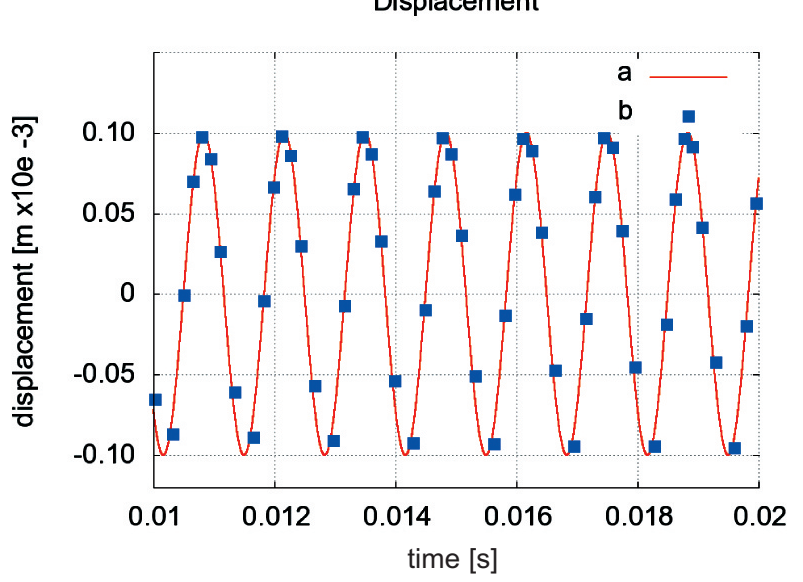

b)

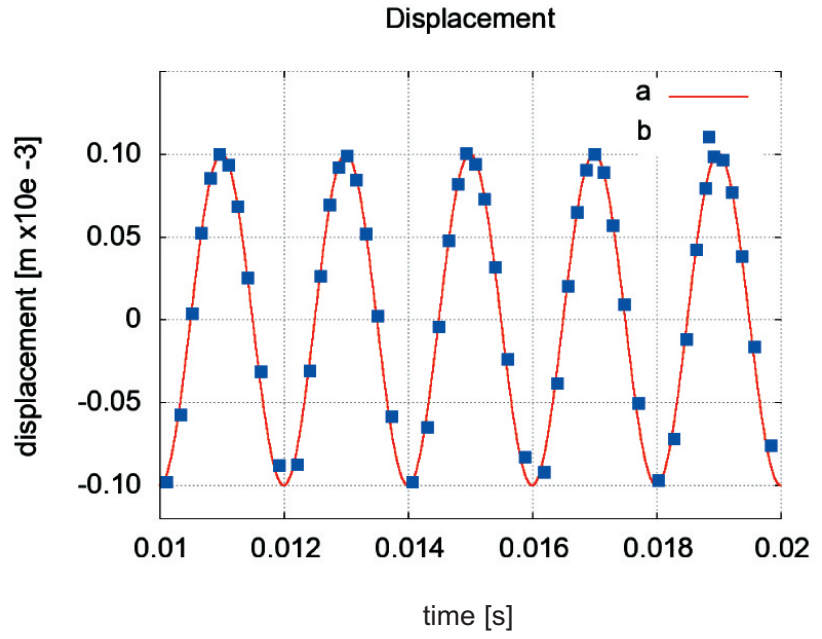

d)

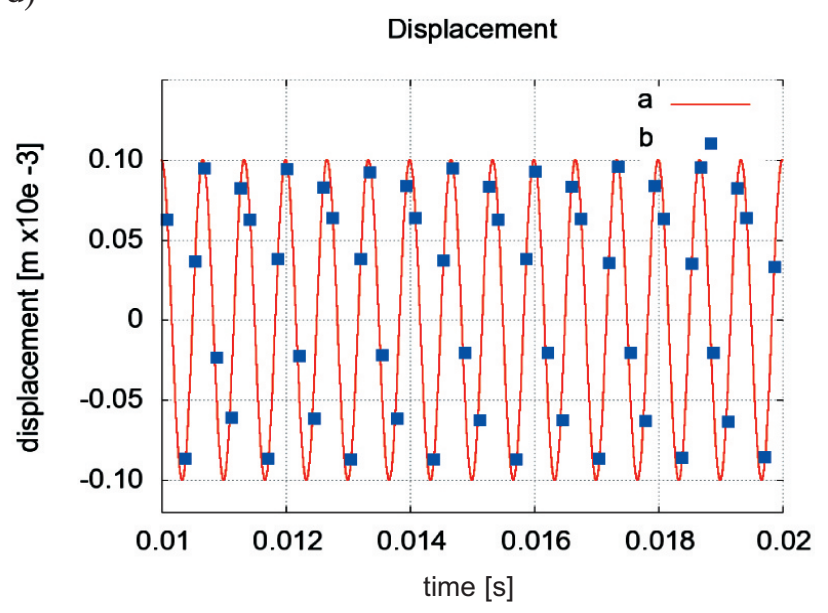

Fig. 9. Displacements given (curve "a") and calculated (curve "b") based on wire frequencies determined from model for force frequencies of: a) $50 \mathrm{~Hz}$; b) $100 \mathrm{~Hz}$; c) $200 \mathrm{H}$; d) $450 \mathrm{~Hz}$. Wire length $-0.05080 \mathrm{~m}$

\section{CONCLUSIONS}

The mathematical model of the vibrating wire extensometer with self-excited vibration force that was built and studied pointed out the following characteristics of the sensors:

a. Numerical studies indicate high usefulness of the wire gauge for examining dynamic processes, which allows for the construction of measurement systems with durability and a measuring stability of up to 30 years.

b. Extensometers with a vibrating wire allow us to perform measurements of harmonic variables. This measurement may be carried out from a constant value of force to a frequency equal to the lowest frequency of sensor operation (the lowest frequency of transverse wire vibration). Therefore this frequency is limited by the way of determining the frequency of the wire transverse vibration. c. It is possible to measure the step-changeable values of strain. The maximum speed of deformation is limited by the wire model used and the method of its excitation. Maximum values are given in this paper. A higher speed of strain increase causes excitation of the higher natural vibration modes of the wire, which disables further analysis.

d. Determination of the wire's natural frequency by measuring the half-period of oscillation causes that the sampling frequency of the signal from the sensor changes over time (depending on changes in the measured quantity).

\section{References}

Bednarski Ł., Sieńko R., 2013, Pomiary odksztatceń konstrukcji za pomoca czujników strunowych. Inżynieria i Budownictwo 11, 615-619. 
Cieplok G., Kopij Ł., 2013, Problemy pomiarów odkształceń szybkozmiennych prowadzonych za pomoca tensometrów strunowych. Modelowanie Inżynierskie 17(48), 13-18.

Cornelsen S., Jacobsen L., 2012, Instrumentation for making high-precision dynamic vibrating wire measurements using standard single coil gages. CSI White paper.

Feldman A.I., Ellis H.L., Smith R.E., Meyerholtz S.J., 2006, Vibrating wire gages monitor dynamic structural integrity during blasting. 32nd Annual Conference, International Society of Explosives Engineers, Dallas, TX.
Kanciruk A., 2004, Wykorzystanie strunowych przetworników deformacji do pomiarów dynamicznych. XXVII Zimowa Szkoła Mechaniki Górotworu, Geotechnika i Budownictwo Specjalne, Zakopane, 14-18 marca, tom 1, red. D. Flisiak, 81-92.

McRae J., Simmonds A., 1991, Long-term stability of vibrating wire instruments, one manufacturer's perspective. 3rd International Symposium on Field Measurements in Geomechanics; Oslo, Norway Sørum (Ed.) Balkema, Rotterdam, vol. 1, 283-293. Simmonds A., 2013, Long term monitoring using vibrating wire sensors. The 6th International Conference on Structural Health Monitoring of Intelligent Infrastructure, 9-11 December, Hong Kong. 